\title{
Integrated coastal zone management in the Patos Lagoon Estuary (South Brazil): state of art
}

\author{
P. R. A. Tagliani, M. L. Asmus, C. R. A. Tagliani, M. Polette, \\ C. S. B. Costa \& E. Salas \\ Department of Oceanography, Federal University of Rio Grande, Brazil
}

\begin{abstract}
In the context of the extensive Brazilian coastal zone, the Patos Lagoon estuary comes across as the contemporary dilemma between the economic development and the environmental conservation in a conspicuous way. Deep changes in the environmental and socioeconomic scenario are expected in the near future, due to the big projects of economic development planned for the region, such as a paper mill industrial complex, a deepening of the navigation channel of the estuary from 15 to $18 \mathrm{~m}$ and the implantation of a shipyard to build up petroleum marine platforms.

Taking into consideration such trends, a program of Integrated Coastal Zone Management at Patos Lagoon estuary - Costa Sul Program, has been conducted since 2005 with the purpose of promoting sustainable development in this estuary. The project is oriented to four main strategies: 1) building capacity in the local government and empowerment of the local community; 2) restoration of coastal habitat and fishery resources; 3 ) to provide alternatives of rental for the rural coastal communities; and 4) to develop a comprehensive coastal management plan with active participation of the civil society, integrating the federal and state environmental policies, and programs and projects with the local ones. This paper will describe some results obtained at this time and will present some lessons learned.
\end{abstract}

Keywords: coastal zone, integrated management, estuaries. 


\section{Introduction}

One of the biggest challenges to be faced for Latin America in this $21^{\text {st }}$ century is the overcoming of the historical barriers that hinder full economic development, promoting the technological transition with social justice and ecological equilibrium. Such a challenge is particularly aggravated in the coastal zones that constitute ecozones of high biodiversity, where there is the concentration of 60 of the 77 largest cities and approximately $60 \%$ of the population of 475 million people (Hinrichsen, In: IDB, [1]), becoming a focus of conflicting interests related to the use and the conservation of the coastal resources. The fragmentation of institutions, public policies, and human/financial resources, is pointed out by some authors as the main difficulty with respect to an effective Integrated Coastal Zone Management (ICZM), and consequently lead to a maintenance and/or aggravation of the conflicts of uses. Such is the situation of the Patos Lagoon estuary, south Brazilian coastal zone (between the parallels $31^{\circ}$ $47^{\prime} 0$ and $32^{\circ} 39^{\prime} 45^{\prime} ' \mathrm{~S}$ and meridians $52^{\circ} 03^{\prime} 10^{\prime \prime} / 52^{\circ} 44^{\prime} 10^{\prime}$ ' W) where the worldwide trend of reduction in the fisheries productivity $[\mathrm{FAO}, 2]$, and the absence of income alternatives in the fishing communities, produce a vicious circle of reduction of the fishery resources, and increase of the poverty in such communities. On the other hand, the peripheral urban communities have suffered the consequences of uncontrolled industrial and urban development during the last three decades, what has been reflected in environmental deterioration, as well as reduction of their quality of life [3-5].

The region of the low Estuary of the Patos Lagoon is shared by the cities of São José do Norte, with 24,877 inhabitants and Rio Grande, with 193,789 thousand inhabitants, occupying the $6^{\text {th }}$ position in the economic ranking of the Rio Grande do Sul state. This economic development, however did not cope with social development, as testified by the Human Development Index of the city that is relatively low in comparison with other cities of the state (Tagliani et al. [4]); The main stakeholder in the local economy has been the port of Rio Grande whose importance will tend to increase in the near future due to a number of investments that are being applied in infrastructure. The entrance of new stakeholders in the areas of forestry and production of cellulose allows one to foresee the deepening of the transformations that are operating in the economic, territorial and environmental scenario at a regional level.

Aiming to promote sustainable development in the low estuary of the Patos Lagoon, a Plan of Integrated Management in the region - Costa Sul Program has been implemented since 2005 with the technical support of the local university, with the partnership of public and private institutions, as well as NGOs. The program was conceived on four strategic and integrated lines: 1) building capacity in the local government and empowerment of the local community; 2) restoration of coastal habitat and fishery resources; 3 ) to provide alternatives of rent for the rural coastal communities, and 4) to develop a comprehensive coastal management plan with active participation of the civil society, integrating the federal and state environmental policies, programs and projects with the local ones. The main activities in development include: a) the 
development of an integrated environmental monitoring system of the estuary, b) the development of a Geographic Information System; c) the development of hydrodynamic and of quality of water patterns; d) the development of sustainable aquaculture of shrimp e) the recuperation of the city garbage deposit, the restoration of salt marshes, of estuarine coves, of the system of coastal dunes, f) the development of agroecology for the rural communities and urban peripheries and the development of ecotourism; g) the elaboration of a plan of fishery management and the Portuary Environmental Agenda among others. All these actions constitute instruments of an Integrated Management Plan (h), elaborated with the participation of the organized civil society, which is presently in its adoption phase (table 1). The program has not yet reached its evaluation phase.

Table 1: $\quad$ Strategic lines, activities and steps in the ICZM Program according to the cycles identified by Olsen and Uchoa [6] for the Integrated Costal Zone Management: 1) Diagnosis; 2) Planning; 3) Adoption; 4) Implementation; 5) Evaluation.

\begin{tabular}{|l|l|l|}
\hline Strategic lines & Activities & steps \\
\hline Building capacities & A,B,C,G,H & 1,2 \\
\hline Habitat and resource recovery & $\mathrm{D}, \mathrm{G}, \mathrm{E}$ & $1,2,3,4$ \\
\hline Generation of economic alternatives & $\mathrm{D}, \mathrm{F}$ & $1,2,3$ \\
\hline Management Plan & $\mathrm{H}$ & $1,2,3,4$ \\
& & \\
\hline
\end{tabular}

\section{Main results}

\subsection{Integrated management plan}

Similarly to many Latin American countries, the environmental management in the Patos Lagoon estuary has been characterized by the adoption of fragmented policies and located and unarticulated sectorial focus. Consequently, the decisive processes have been fragmented, reactive and with few expressive results concerning the point of view of behavioral changes in the society and in the environmental quality of the coastal ecosystem.

The Costa Sul Program has adopted the cooperative planning model, opposing the models that Müller [7] called DeAD (Decides, Approves, Defends) prevailing in the local structures of planning (Salas [8]).

The cooperative model is being initially tested in small scale, in the Marinheiros Island, the largest island of the estuary, where a community of 1,400 people, among them fishermen and farmers, lives. After a number of workshops through the year of 2006, with the intense involvement of the local community, university and city government, an Environmental Management Plan for this island was elaborated. The main results obtained to date can be considered: 1) the preparation of an agenda of priority themes to be worked on in the next five years; 2) the organization of the social participants due to the existing conflicts and problems; 3) the process of construction of an empowerment 
agenda of the communities before the decision making organs; 4) the implementation of a local management committee and of some goals established by the committee.

Once the Management of Marinheiro Island was adopted and implemented, the Costa Sul Program carried out the Management Plan of Patos Lagoon estuary on a broader scale. This plan has concentrated efforts in order to promote a transition of a present situation, of weak sustainability, marked by the disarticulation of policies and programs, institutions/resources and civil society, for a situation of strong sustainability where these start integrating coordinated strategic actions (Gómez [9]) (figure 1). Currently the integrated management plan is concluded in a participative way with the civil society and is now in the adoption phase.

\subsection{Income alternatives creation}

\subsubsection{The pilot project sustainable shrimp aquaculture}

The estuary of the Lagoa dos Patos is a natural habitat for the Farfantepenaus paulensis, therefore, this species is perfectly adapted to the environment. Since 2005 the local university has carried on efforts to develop small scale projects of shrimp aquaculture, on a familiar basis, aiming to provide to the fishermen an income alternative to the fishery. The structure's cultivation consists of low cost technology, using fences set up with bamboos and fine mash nets in the shallow estuarine waters. The fishermen and their family members are assisted with training courses in the fishing, associations and aquaculture areas.

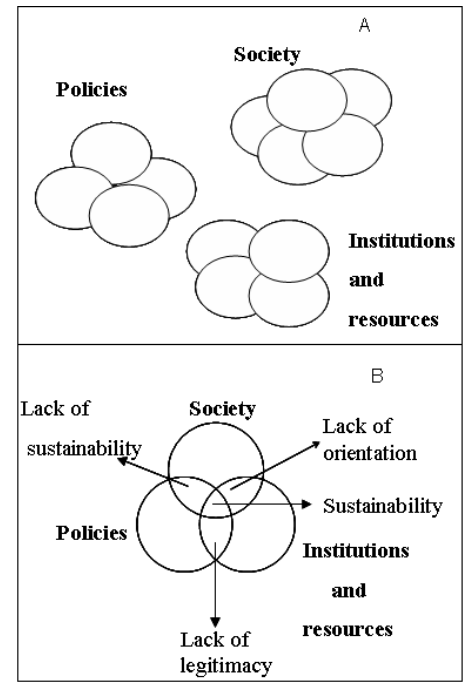

Figure 1: Conceptual framework of the strategy of the Integrated Management Plan of Patos Lagoon Estuary based on Gómez [9]; A) Scenery of weak sustainability; B) The common area between the three circles promotes the best conditions to the sustainability. 
In parallel, the university carries on the technical support with the monitoring of water quality and researches applied in the field of physiology, ecology, land use planning and numerical modeling of the hydrodynamic and water quality in order to implement the activity of aquaculture in a sustainable way. At the end of January 2006, four structures of fences were installed and monitored. The product of the cultivation was identified with a stamp of the university, in order to differentiate the cultivated shrimp from the caught one. This measure made it possible to add value to the product, which was commercialized for US\$ $5.5 / \mathrm{kg}$, a value four times superior to the one charged for the caught shrimp. Nevertheless the efforts of the local university, which each year has subsidized the implantation of pilot projects, the involvement of the fishermen is still incipient and a great difficulty persists for the effective implantation of the cultivation of the native shrimp in the estuary.

\subsection{Habitat recovery}

\subsubsection{Salt marsh restoration}

In sedimentary coastal regions, the water quality in shallow water bodies depends on the rooted vegetation that constitutes most part of the substrate for the settling of microorganisms which purify the water (processes of mineralization, nitrification, denitrification, etc.) (Hammer [10]). The increase of plant covering on the margins of lakes and lagoons results in the increment of the number of invertebrates and bigger reproductive success of aquatic birds (Chambers and McComb [11]). Consequently, rapid improvement in the quality of water and the trophic structure of anthropogenic impacted lakes and lagoons can be active by a plan of propagation and establishment of plants adapted to periodic flooding, such as grasses and sedges.

Over the last two centuries landfilling for urban and industrial development has destroyed several hectares of salt marshes in the main estuarine areas of Patos Lagoon. Creation and restoration of coastal marshes is nowadays a critical conservation issue facing the cumulative loss of wetlands and depreciation of remaining environments. The demonstrative project of the restoration of salt marshes which is being conducted in the ambit of the Costa Sul Program aims at: - reverting the cumulative losses of vital areas of salt marshes in the Patos Lagoon estuary, through the restoration, creation and improvement of some selected units of salt marsh;

- intercepting, temporary stocking and/or breakdown part of the several contaminants normally present in the urban runoff of Rio Grande city through the transposition of dense vegetated stands of salt marshes between effluent damping points and the main body of the lagoon.

- mitigating erosive margins, exposed to dominant winds from the northeast and southeast, through the re-vegetation with native species.

- using the restoration activities of the project to promote the public awareness of the importance of salt marsh environments for the quality of life in the coastal zone.

The recuperation of salt marsh involves the activities of production of seedling and vegetative propagules, establishment of the transplants, monitoring 
of the created/restored salt marshes, distribution of advertising material and actions of environmental education. In the first year of the project a marsh area of $10,000 \mathrm{~m}^{2}$ was recuperated by planting cordgrass Spartina alterniflora propagules, spaced $1 \mathrm{~m}$ apart, along slightly erosive margins and across urban runoff drains (figure 2).
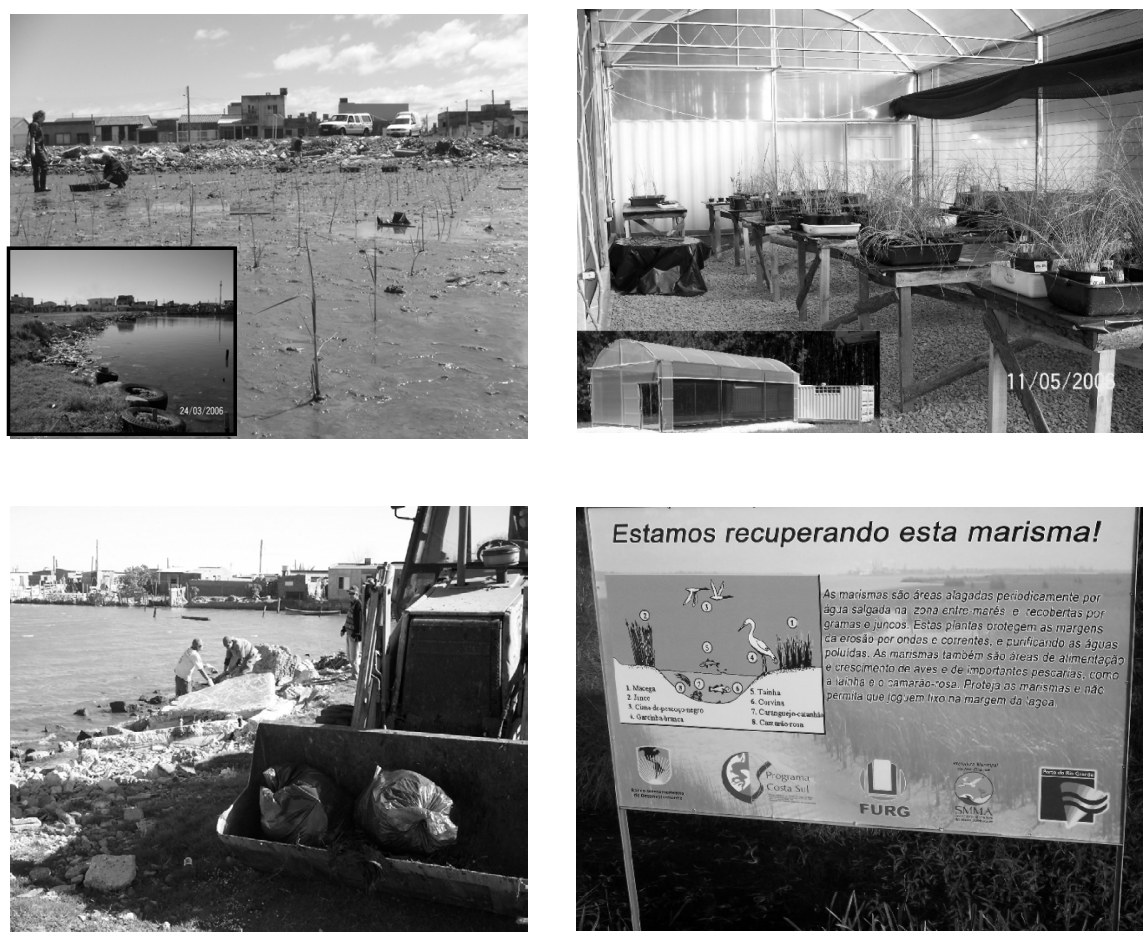

Figure 2: a) Salt marsh restoration in the margins of the urban area of Patos Lagoon estuary, using Spartina alterniflora. The inserted figure shows the same estuarine embayment before the plantation of Spartina; b) The "Spartinário" installed at the university to produce the plants from seeds; the insert shows the external area of the greenhouse; c) The removal of debris to prepare the terrain; d) The educative panel installed nearby a restoration site.

\subsubsection{Sand dune restoration}

Among the actions of recuperation of coastal resources, the Costa Sul Program has worked towards the strengthening of the project of recuperation of coastal dunes which is being conducted by Rio Grande City government through the efforts of a local NGO. This effort resulted in the elaboration of a Management Plan of the coastal dunes which includes among other aspects a plan of territorial ordering on the beach zone. The management plan of the coastal dunes started to constitute one of the management instruments of the ICZM. 


\subsection{Empowerment of the artisanal fishermen communities}

Currently, common sense exists in the ambit of Costa Sul Program that any effort applied to solve the crisis in the fishery sector will not be effective without the participation of the fishermen in the decision making instances. The artisanal fishermen community of Patos Lagoon estuary are politically organized in a sectorial Forum (Patos Lagoon Forum) formed by 15 public entities. The Costa Sul Program have carried out efforts to improve the role of participation of the fishermen in such forum, and building up a collaborative management plan for the artisanal fishery of Patos Lagoon estuary through out a series of workshops with an effective participation of the artisanal fishermen community.

\section{Lessons learned}

The superposition and the antagonism of interests of the public and private organizations, associated to the lack of capable human resources, constitute major obstacles for an effective integrated coastal management. The integration of the institutional matrix and the social participants strengthens and enlarges the governance, establishing the basic conditions for the promotion of sustainable development. The integration needs before hand, a correct identification of the stakeholders, and of a diagnosis of the institutional structure which enables identifying the responsibilities of each organization in the hierarchical structure of the public administration, its strengths, fragilities, opportunities and threats for the integrated coastal management,

On the other hand, the development of demonstrative projects of low scale, has permitted reaching concrete results in a short term. Such strategy has demonstrated being a useful instrument of learning and to convince and induce positive behavioral changes both in the public as well as in the private sector. In the case of the Environmental Plan of Marinheiro Island, the most expressive result was the process of building up the environmental agenda, which resulted in the empowerment of the local community and strengthened its group identity.

\section{Acknowledgements}

This study has received financial support from Inter-American Development Bank /Japanese Special Fund. ATN/JF 7354 - BR and Brazilian Government SEAP.

\section{References}

[1] IDB Strategy Paper. Coastal and marine resources management in Latin America and the Caribbean. Inter-American Development Bank Document. Number ENV 129.Washington, D.C. 1998

[2] FAO (Food and Agriculture Organisation of the United Nations). The state of world fisheries and aquaculture. Rome: FAO; 2002 
[3] Niencheski,F. \& Baungartem.M.G.Z. Hidroquímica. In: : Tagliani, P. R. A. \& Asmus M.L. (Coord.). Estudo de Impacto Ambiental do Porto de Rio Grande. FURG. Documento Técnico. pp.491-545. In, 850 pp. 1997

[4] Tagliani, P.R.A., Landázuri, H., Reis ,E.,Tagliani, C.R.; Asmus, M. \& Arcilla, A.S. Integrated coastal zone management in the Patos Lagoon estuary: Perspectives in context of developing countries. Ocean and Coastal Management, Elsevier 46 .807-822. 2003)

[5] Almeida, M.T.A; Baungarten,M.G.Z.; Rodrigues R.M.S. Identificação das Possíveis Fontes de Contaminação das Águas que margeam a cidade de Rio Grande, Documentos Técnicos, Editora da FURG, 29p. 1993

[6] Olsen, S. B.; Ochoa, E. 2004. Folhas de Aplicação do Caderno de Trabalho. Marco metodológico e conceitual para o Planejamento e Implementação do Gerenciamento de Ecossistemas Costeiros. 33p

[7] Müller, B.: Redes de Cooperación y el Dilema de la Participación. Ponencia en la conferencia "Ordenamiento Territorial y Participación". Concepción. 2002

[8] Salas, E. Diálogos políticos: poniendo en práctica la gobernanza costera. En: Cooperación en el Espacio Costero. Ecoplata (en proceso de publicación).

[9] Gómez, R. Personal communication. Conference title: "Good Governance". GTZ workshop Recife, Brasil. 2005

[10] Hammer, D.A. Designing constructed wetlands systems to treat agricultural nonpoint source pollution. Ecological Engineering, 1: 49-82. 1992

[11] Chambers, J.M. \& McComb A.J. Establishment of wetland ecosystems in lakes created by mining in Western Australia. In: Mitsch, W.J. (ed.). Global Wetlands: Old World and New. Elsevier, Amsterdam, pp. 431-441. 1994. 